\title{
Biocatalytic One-Carbon Ring Expansion of Aziridines to Azetidines via a Highly Enantioselective [1,2]-Stevens Rearrangement
}

\author{
David C. Miller, ${ }^{\dagger}$ Ravi G. Lal, ${ }^{\dagger}$ Luca A. Marchetti, ${ }^{\dagger} \S$ and Frances H. Arnold*,† \\ † Division of Chemistry and Chemical Engineering, California Institute of Technology, Pasadena, California 91125 \\ $\S$ Present Address: Department of Biosystems Science and Engineering, ETH Zürich, 4058 Basel, Switzerland
}

\begin{abstract}
We report enantioselective one-carbon ring expansion of aziridines to make azetidines as a new, abiologcal ac-

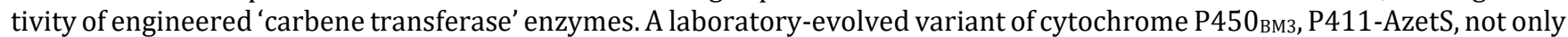
overrides the inherent reactivity of aziridinium ylides to undergo cheletropic extrusion of ethylene, it also exerts unparalleled stereocontrol (99:1 er) over a [1,2]-Stevens rearrangement, a notoriously challenging reaction class for asymmetric catalysis. These unprecedented selectivities enable an entirely new strategy for the synthesis of chiral azetidine products from readily available synthetic precursors. The utility of this reaction is highlighted by the synthesis of an enantiopure azetidine on gram scale. The exquisite selectivity of the enzyme enables new-to-nature ring-expansion chemistry that overcomes a longstanding synthetic problem.
\end{abstract}

Ring-size manipulation has emerged as a powerful strategy to convert readily available cyclic structures into ringexpanded or ring-contracted compounds that are more difficult to synthesize using conventional means. ${ }^{1}$ In particular, "cut and sew" strategies relying on transition-metal catalyzed oxidative addition to form $\mathrm{C}-\mathrm{C}$ bonds have emerged as powerful tools for insertion of carbon monoxide or twocarbon fragments such as olefins and alkynes into existing rings to effect one- or two-carbon ring expansions, respectively. ${ }^{2}$ For nitrogen-containing heterocycles, one possible strategy is to induce a $[1,2]$-Stevens rearrangement to enact a one-carbon ring expansion. ${ }^{3}$ Pioneering work by Hata, West, and Couty has demonstrated the power of this approach for 4- to 5-membered ring expansions, wherein treatment of an azetidine with a diazo compound in the presence of a copper catalyst provides facile access to the corresponding pyrrolidine. ${ }^{4}$ Conceptually, carbene transfer followed by an intramolecular [1,2]-Stevens rearrangement complements "cut and sew" reactions for non-carbonylative, one-carbon homologation of nitrogen-containing compounds. Given the prevalence of nitrogen heterocycles across numerous sectors of chemical industry, especially pharmaceuticals, ${ }^{5}$ general strategies to extend this approach to other nitrogen-containing compounds would represent a powerful new approach for the synthesis of important pharmacophores.

Azetidines are valuable isosteres of pyrrolidines and piperidines, as they often have enhanced metabolic stability and potency compared to their 4- and 6-membered ring congeners. $^{6}$ Azetidines are underexplored in medicinal chemistry due to the lack of robust synthetic strategies to access them, ${ }^{7}$ particularly in enantioenriched form. ${ }^{8}$ Stateof-the-art methodologies such as [2+2] cycloadditions of imines and olefins, ${ }^{9}$ have been developed to address the lack of robust methods for the synthesis of azetidines. ${ }^{10}$ However, direct synthesis of enantioenriched azetidines using asymmetric catalysis has remained elusive. Application of a ring-expansion strategy for the asymmetric, one-carbon homologation of aziridines via carbene insertion would be a powerful new entry for the synthesis of chiral azetidines. However, this approach comes with two major selectivity challenges that, to date, have not been addressed in a general fashion. The first is the innate reactivity of the intermediate aziridinium ylides, which undergo highly favorable cheletropic extrusion of ethylene in many contexts. ${ }^{11}$ While these intermediates can be harnessed in [2,3]-Stevens rearrangements and other ring-opening reactions, ${ }^{12}$ no examples of [1,2]-Stevens rearrangements from aziridinium ylides have been reported. Secondly, the diradical mechanism of the $[1,2]$-Stevens rearrangement ${ }^{13}$ has made it a challenging reaction for asymmetric synthesis. Few asymmetric variations of this reaction have been reported. ${ }^{14}$ Enantiopure quaternary ammonium salts can undergo [1,2]Stevens rearrangements with $N$-to- $C$ chirality transfer; ${ }^{15}$ however, escape of the radical pair from the solvent cage is often competitive with radical recombination, ${ }^{16}$ and erosion of enantiopurity is often observed in these reactions. The joint selectivity challenges presented by the one-carbon ring expansion of aziridines into azetidines not only require a potential catalyst to select the [1,2]-Stevens rearrangement in preference to cheletropic extrusion of ethylene but also to exert enantiocontrol over a potential diradical intermediate. We are unaware of any successful examples of a one-carbon ring expansion of aziridines through a $[1,2]$-Stevens rearrangement strategy. 
Cytochrome P411

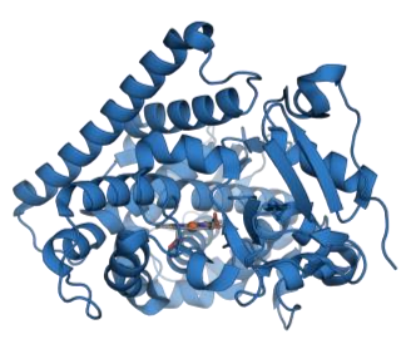

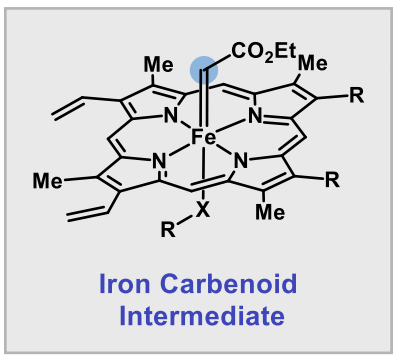

Iron Carbenoid
Established Reactivity of Iron Carbenoids

1. Addition to $\pi$-systems: 2 C-C Bonds Formed<smiles>C=Cc1ccccc1</smiles><smiles>CCOC(=O)C=N</smiles>

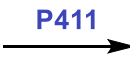

Access to cyclopropanes, cyclopropenes, and bicyclobuanes

2. Addition to $\mathrm{X}-\mathrm{H}$ Bonds: $1 \mathrm{C}-\mathrm{H}$ and one $\mathrm{C}-\mathrm{X}$ Bond Formed

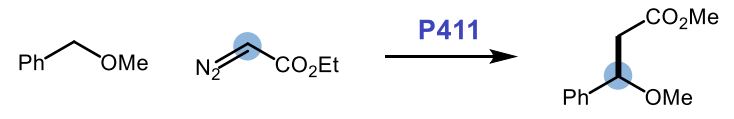

Insertion into $\mathrm{C}-\mathrm{H}, \mathrm{Si}-\mathrm{H}, \mathrm{B}-\mathrm{H}, \mathrm{S}-\mathrm{H}$, and $\mathrm{N}-\mathrm{H}$ Bonds

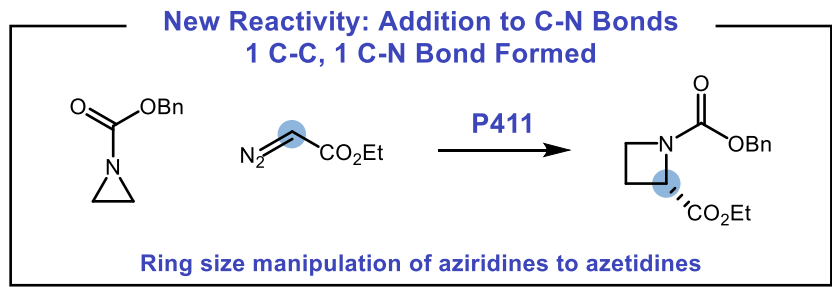

Figure 1: Classification of enzyme-mediated carbene transfer reactions for various bond disconnections.

Nature utilizes ring size manipulation in the biosynthesis of natural products, with common strategies for biocatalytic one-carbon ring expansion including oxidative ring expansions ${ }^{17}$ and carbocation rearrangements. ${ }^{18}$ We hypothesized that engineered carbene transferases could potentially extend enzymatic ring expansions through a [1,2]Stevens-type mechanism (Figure 2). Over the past decade, enzymes derived from cytochrome $\mathrm{P} 450_{\text {вмз }}$, such as cytochromes P411, and other hemoproteins have emerged as powerful catalysts for carbene transfer reactions, ${ }^{19}$ and formation of strained rings such as cyclopropanes and cyclopropenes with excellent stereoselectivities has been reported..$^{20}$ The most common reactions of the iron-carbenoid intermediate are additions across $\pi$-systems or $\mathrm{X}-\mathrm{H}$ bond insertions: ${ }^{21} \mathrm{C}-\mathrm{N}$ bond insertion through Stevens rearrangements of any kind have yet to be reported. We envisioned that the reaction of a hemoprotein with a suitable carbene precursor could form an electrophilic iron-carbenoid intermediate, which could be trapped by a sufficiently nucleophilic aziridine. Ammonium ylides are commonly proposed as intermediates in carbene $\mathrm{N}-\mathrm{H}$ insertion reactions, ${ }^{22}$ supporting the feasibility of this step. Finally, the aziridinium ylide could potentially undergo the desired $[1,2]$-Stevens rearrangement preferentially over cheletropic extrusion of ethylene, liberating the desired product and regenerating the hemoprotein-if this chemoselectivity could be achieved, we hypothesized that the enzyme may be able to control the stereoselectivity of this reaction. Hemoproteins demonstrate high stereoselectivity in radical reactions, both in their native activity ${ }^{23}$ and in abiological reactions cultivated through protein engineering. ${ }^{24}$ In addition, we envisioned that the active site of an enzyme could mimic solvent cage effects which are known to exert control over radical recombination in $[1,2]$ Stevens rearrangements. ${ }^{16}$ Provided an enzyme could overcome both of these selectivity challenges, this approach could be a facile and powerful strategy to access enantioenriched azetidines.

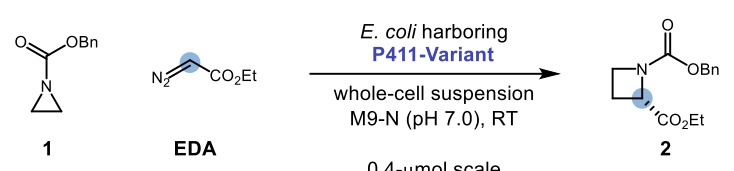

\begin{tabular}{cccccc} 
Entry & Variant & $\begin{array}{c}\text { Mutations Relative } \\
\text { to Prior Generation }\end{array}$ & TTN & Yield (\%) & e.r. \\
\hline 1 & Parent F2 & None & 73 & 3.6 & $90: 10$ \\
2 & F2.1 & G263Y & 70 & 3.5 & $75: 25$ \\
3 & F2.2 & T327V & 126 & 6.3 & $56: 44$ \\
4 & F2.3 & A330T & 193 & 9.6 & $59: 41$ \\
5 & F2.4 & H266P & 394 & 19.7 & $62: 38$ \\
6 & F2.5 & M177Q & 699 & 34.9 & $94: 6$ \\
7 & F2.6 & T436G & 945 & 47.3 & $93: 7$ \\
8 & F2.7 & L233F & 997 & 49.8 & $94: 6$ \\
9 & F2.8 & T149M & 1040 & 52.0 & $99: 1$ \\
10 & F2.9 & R47Q & 1190 & 59.7 & $99: 1$ \\
11 & P411-AzetS & M118K & 1200 & 59.9 & $99: 1$
\end{tabular}

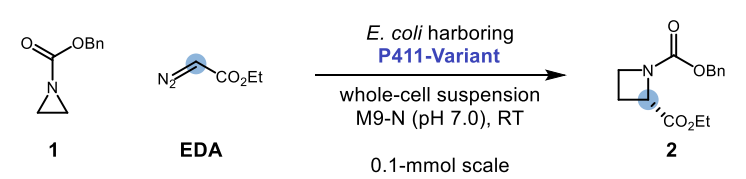

\begin{tabular}{ccccc} 
Entry & Change from Conditions Above & TTN & Yield (\%) & e.r. \\
\hline 12 & None & 1583 & 79.1 & $99: 1$ \\
13 & $20 \mathrm{mM} \mathrm{[1]} ; 30 \mathrm{mM}[\mathbf{E D A}]$ & 2200 & 55.0 & $99: 1$ \\
14 & Lysate & 1090 & 54.4 & $99: 1$ \\
15 & Lysate; $20 \mathrm{mM} \mathrm{[1];30} \mathrm{mM} \mathrm{[EDA]}$ & 1570 & 39.3 & $99: 1$ \\
16 & $4{ }^{\circ} \mathrm{C}$ & 1610 & 80.2 & $99: 1$ \\
17 & Lysate; $4{ }^{\circ} \mathrm{C}$ & 1380 & 68.7 & $99: 1$
\end{tabular}

Figure 2: Putative catalytic cycle for one-carbon ring expansion of aziridines to furnish chiral azetidines, as well as cheletropic extrusion of ethylene as a possible side reaction.

We initiated our studies by screening a panel of hemoproteins for the model reaction of benzyl azirdine-1-carboxylate 1 with ethyl diazoacetate (EDA) as a carbene precursor to provide enantioenriched azetidine 2 (Table 1) in suspensions of Escherichia coli (E. coli) whole cells. The highest activity for this reaction was observed with a variant of P411 вм3-CIS ${ }^{25}$ with the additional mutations P248T, I263G, and L437F ("Parent F2"), providing the product with 3.7\% yield, 73 total turnover number (TTN), and 90:10 er for the (S)-enantiomer (Entry 1). Parent F2 is derived from hemoproteins originally engineered for the cyclopropanation of heteroatom-substituted olefins ${ }^{26}$ and is 17 mutations away from its wild-type progenitor, cytochrome $\mathrm{P} 40_{\text {вмз }}$ from Bacillus megaterium, which natively catalyzes the oxidation 
of long-chain fatty acids. ${ }^{27}$ Control experiments revealed that hemin is unable to catalyze this reaction (see SI for details). Encouraged by this promising initial activity and high enantioselectivity, we chose Parent F2 as a starting point for directed evolution to improve enzyme performance using iterative site-saturation mutagenesis (SSM) of residues located in the heme domain (Entries 2-11) and screening for improved azetidine yield by gas chromatography.

Table 1: Lineage and Reaction Optimization ${ }^{a}$

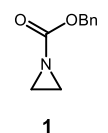<smiles>CCOC(=O)CC</smiles>

EDA

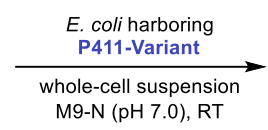

$0.4-\mu \mathrm{mol}$ scale

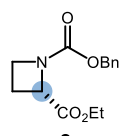

\begin{tabular}{cccccc} 
Entry & Variant & $\begin{array}{c}\text { Mutations Relative } \\
\text { to Prior Generation }\end{array}$ & TTN & Yield (\%) & e.r. \\
\hline 1 & Parent F2 & None & 73 & 3.6 & $90: 10$ \\
2 & F2.1 & G263Y & 70 & 3.5 & $75: 25$ \\
3 & F2.2 & T327V & 126 & 6.3 & $56: 44$ \\
4 & F2.3 & A330T & 193 & 9.6 & $59: 41$ \\
5 & F2.4 & H266P & 394 & 19.7 & $62: 38$ \\
6 & F2.5 & M177Q & 699 & 34.9 & $94: 6$ \\
7 & F2.6 & T436G & 945 & 47.3 & $93: 7$ \\
8 & F2.7 & L233F & 997 & 49.8 & $94: 6$ \\
9 & F2.8 & T149M & 1041 & 52.0 & $99: 1$ \\
10 & F2.9 & R47Q & 1193 & 59.7 & $99: 1$ \\
11 & P411-AzetS & M118K & 1198 & 59.9 & $99: 1$
\end{tabular}

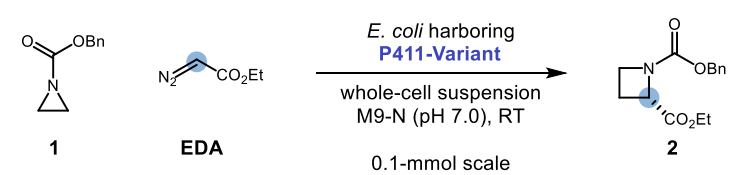

\begin{tabular}{ccccc} 
Entry & Change from Conditions Above & TTN & Yield (\%) & e.r. \\
\hline 12 & None & 1583 & 79.1 & $99: 1$ \\
13 & $20 \mathrm{mM}[\mathbf{1}] ; 30 \mathrm{mM}$ [EDA] & 2198 & 55.0 & $99: 1$ \\
14 & Lysate & 1089 & 54.4 & $99: 1$ \\
15 & Lysate; $20 \mathrm{mM} \mathrm{[1];30} \mathrm{mM} \mathrm{[EDA]}$ & 1572 & 39.3 & $99: 1$ \\
16 & $4{ }^{\circ} \mathrm{C}$ & 1605 & 80.2 & $99: 1$ \\
17 & Lysate; $4{ }^{\circ} \mathrm{C}$ & 1375 & 68.7 & $99: 1$
\end{tabular}

${ }^{a}$ Reactions were performed on the designated scale and run for $16 \mathrm{~h}$ with $10 \mathrm{mM}$ of $1,15 \mathrm{mM}$ of EDA, and $5 \mu \mathrm{M}$ of protein. TTN and yields were determined via GC analysis of crude reaction mixtures relative to internal standard and represent the average of three experiments. The enantiomeric ratio (er) was determined by chiral GC.

Sites were selected for mutagenesis based on success in previous directed evolution campaigns of $\mathrm{P} 450_{\text {вмз }}$ as well as prior knowledge of residues responsible for substrate binding and catalysis in the heme domain of this protein scaffold. ${ }^{17 a}$ Ten beneficial mutations were identified during this campaign, resulting in a more efficient 'azetidine synthase' (P411-AzetS) with a net improvement of 16-fold in TTN and 99:1 er. With P411-AzetS in hand, we next examined the impact of varying the reaction conditions on the product yield (Entries 12-17). Notably, increasing the scale from $4 \mu \mathrm{mol}$ to $100 \mu \mathrm{mol}$ resulted in an increase in the reaction yield. When the concentrations of $\mathbf{1}$ and EDA were doubled to 20 $\mathrm{mM}$ and $30 \mathrm{mM}$, respectively, a decrease in reaction yield was observed (although TTN increased). The ring expansion reaction also proceeded in clarified cell lysate, albeit with decreased yields when compared to analogous reactions performed with whole-cell suspensions. Lastly, decreasing the reaction temperature from 22 to $4{ }^{\circ} \mathrm{C}$ did not have a meaningful impact on the reaction yields when run in whole-cell suspensions.

Next, we sought to examine the substrate scope of this reaction. When this reaction was run at $0.5-\mathrm{mmol}$ scale, azetidine 2 could be formed in 75\% yield, 1490 TTN, 67\% yield, and 99:1 er. Other aromatic groups could be used in lieu of a phenyl group with uniformly high enantioselection observed in all cases.

\section{Scheme 1: Substrate Scope ${ }^{a}$}<smiles>O=C([O-])N1CC1</smiles>

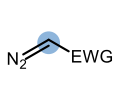

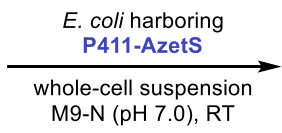<smiles>[R]OC(=O)N1CC[C@H]1C(C)(C)C</smiles><smiles>CCOC1CCN1C(=O)OCc1ccccc1</smiles>

2 $75 \%(67 \%)$ yield, 1490 TTN, $99: 1$ er<smiles>CCOC1CCN1C(=O)OCc1cccs1</smiles>
3 $38 \%(38 \%)$ yield, 764 TTN, 99:1 er<smiles>CCOC1CCN1C(=O)OCc1ccc(F)cc1</smiles>

4 $31 \%(27 \%)$ yield 626 TTN, 99:1 er<smiles>CCCOC(=O)N1CC[C@H]1C(=O)OCc1ccccc1</smiles>
7 $18 \%(17 \%)$ yield 363 TTN, 99:1 er<smiles>CCO[C@H]1CCN1C(=O)OCc1cccc(F)c1</smiles>
5 $34 \%(29 \%)$ yield, 681 TTN, 99:1 er

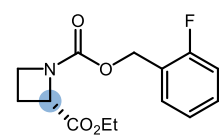

6 $41 \%(36 \%)$ yield, 811 TTN, 99:1 er

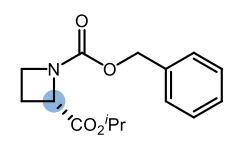
$28 \%(28 \%)$ yield, 564 TTN, >99:1 er

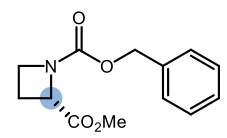

9

$20 \%(18 \%)$ yield, 402 TTN, 81:19 er

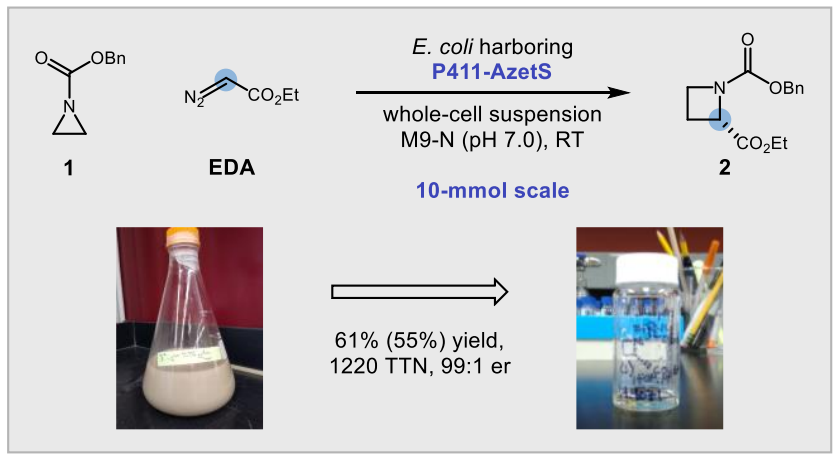

${ }^{a}$ Reactions were performed on $0.5-\mathrm{mmol}$ scale unless otherwise specified. Analytical yields and TTN were determined by GC-FID. Yields for isolated and purified material are designated in parentheses. The er was determined by Chiral GC. For 0.5-mmol scale reactions, all numbers reported represent the average of two trials. For 10-mmol scale reaction, numbers reported represent one run.

Notably, a thiophene-bearing aziridine could undergo chemoselective ring expansion to azetidine $\mathbf{3}$ with no 
observed cyclopropanation byproducts. This selectivity is notable not only because thiophenes are known to react with EDA-derived metal carbenoids under mild conditions, ${ }^{28}$ but also because Parent F2 was originally engineered to perform cyclopropanation of heteroatom-substituted olefins. ${ }^{26}$ Fluorine substituents were also tolerated on the arene ring at the para, meta, and ortho positions to furnish fluorinated products 4-6. In addition to EDA, other diazoacetate compounds could participate in one-carbon ring expansion with at least 99:1 er (7-8). When methyl diazoacetate was used as the carbene precursor to yield $\mathbf{9}$, a notable decrease in er (81:19) was observed. One hypothesis for this decrease in enantiopurity is that the smaller aliphatic chain allows for greater conformational freedom of the iron porphyrin carbene intermediate or the putative diradical intermediate. This explanation is consistent with prior work on enzyme-mediated carbene transfer reactions using perfluoroalkyl-stabilized diazo compounds as carbene precursors, where the substrate chain length has a profound influence on the absolute stereochemistry of the reaction. ${ }^{29}$ The reaction could also be scaled up from 0.5 mmol scale to $10-\mathrm{mmol}$ scale to furnish 2 in 1220 TTN, $61 \%$ yield, and 99:1 er with an isolated yield of $1.44 \mathrm{~g}$ (55\% yield), demonstrating that gram-scale production of enantioenriched azetidines is viable using this platform. Taken together, the unprecedented chemo- and stereoselectivity observed demonstrates the tremendous synthetic potential of this approach for the synthesis of enantioenriched azetidines. Currently, P411-AzetS and its lineage perform poorly with other classes of nitrogen protecting groups (e.g. -Boc, -tosyl, -benzyl, and -hydrocinnamoyl) and do not perform [1,2]-Stevens rearrangements when presented with other acceptor-stabilized diazo compounds. Aziridine substrates with substituents on the carbon backbone of the ring were unable to undergo ring expansion due to their pronounced capacity for ring opening by hydrolysis relative to unsubstituted aziridine rings. Efforts to expand the observed, unprecedented reactivity and selectivity to the synthesis of other classes of azetidines are ongoing.

In summary, we have demonstrated unprecedented hemoprotein-catalyzed [1,2]-Stevens rearrangement in the context of a one-carbon ring expansion of aziridines to azetidines. This system not only represents a rare example of a highly enantioselective [1,2]-Stevens rearrangement of ammonium ylides, it also exhibits unprecedented chemoselectivity for rearrangement of aziridinium ylides over cheletropic extrusion of ethylene. We anticipate that this platform for azetidine synthesis can be extended to other substrate classes for synthesis of other enantioenriched azetidine cores, providing facile access to valuable chiral building blocks. We are optimistic that the reactivities and selectivities observed can be applied to other [1,2]-Stevens rearrangements as well, providing the grounds for future work in this area towards the synthesis of chiral amines.

\section{ASSOCIATED CONTENT}

The Supporting Information is available free of charge at: Supporting Information Placeholder

\section{AUTHOR INFORMATION}

\section{Corresponding Author}

Frances H. Arnold - Division of Chemistry and Chemical Engineering, California Institute of Technology, Pasadena, California 91125, United States; orcid.org/0000-0002-4027364X; Email: frances@cheme.caltech.edu

\section{Authors}

David C. Miller - Division of Chemistry and Chemical Engineering, California Institute of Technology, Pasadena, California 91125, United States; orcid.org/0000-0002-4560$\underline{8824}$

Ravi G. Lal - Division of Chemistry and Chemical Engineering, California Institute of Technology, Pasadena, California 91125, United States; orcid.org/0000-0001-6943-4147.

Luca A. Marchetti - Present address: Department of Biosystems Science and Engineering, ETH Zürich, 4058 Basel, Switzerland; orcid.org/0000-0002-6100-4465

\section{Notes}

The authors declare no competing financial interest.

\section{ACKNOWLEDGMENT}

Research was sponsored by the U.S. Army Research Office and accomplished under contracts W911NF-19-D-0001 and W911NF-19-2-0026 for the Institute for Collaborative Biotechnologies. D.C.M. was supported by a Ruth Kirschstein NIH Postdoctoral Fellowship (F32GM128247). The authors acknowledge Dr. Sabine Brinkmann-Chen, Nathaniel Goldberg, and Dr. Nicholas Porter for assistance preparing the manuscript.

\section{REFERENCES}

(1) (a) Zhao, K.; Yamashita, K.; Carpenter, J.E.; Sherwood, T.C.; Ewing, W.R.; Cheng, P.T.W.; Knowles, R.R. J. Am. Chem. Soc. 2019, 141, 8752. (b) Dherange, B.D.; Kelly, P.Q.; Liles, J.P.; Sigman, M.S.; Levin, M.D. J. Am. Chem. Soc. 2021, doi:10.1021/jacs.1c06287 (c) Kennedy, S.H.; Dherange, B.D.; Berger, K.J.; Levin, M.D. Nature, 2021, 593, 223. (d) Donald, J.R.; Unsworth, W.P. Chem. -Eur. J. 2017, 23, 8780. (e) Dowd, P.; Zhang, W. Chem. Rev. 1993, 93, 2091. (2) For reviews, see: (a) Chen, P.-H.; Billett, B.A.; Tsukamoto, T.; Dong, G. ACS Catal. 2017, 7, 1340. (b) Xu, T.; Dermenci, A.; Dong, G. Top. Curr. Chem. 2014, 346, 233. (c) Gao, Y.; Fu, X.-F.; Yu, Z.-X. Top. Curr. Chem. 2014, 346, 195. (d) Xia, Y.; Dong, G. Nat. Rev. Chem. 2020, 4, 600. (e) Jun, C.-H. Chem. Soc. Rev. 2004, 33, 610. (f) Chen, F.; Wang, T.; Jiao, N. Chem. Rev. 2014, 114, 8613. (g) Souillart, L.; Cramer, N. Chem. Rev. 2015, 115, 9410.

(3) For representative examples, see: (a) Tayama, E. Heterocycles, 2016, 92, 793. (b) Wittig, G.; Tenhaeff, H.; Schoch, W.; Koenig, G. Liebigs Ann. Chem. 1951, 572, 1. (c) Chicharro, R.; de Castro, S.; Reino, J.; Arán, V.J. Eur. J. Org. Chem. 2003, 2003, 2314. (d) Pedrosa, R.; Andrés, C.; Delgado, M. Synlett, 2000, 893. (e) Harthong, S.; Bach, R.; Besnard, C.; Guénée, L.; Lacour, J. Synthesis, 2013, 45, 2070. (f) Vanecko, J.A.; West, F.G. Org. Lett. 2002, 4, 2813. (g) Hanessian, S.; Mauduit, M. Angew. Chem. Int. Ed. 2001, 40, 3810. (h) Liou, J.-P.; Cheng, C.-Y. Tetrahedron Letters, 2000, 41, 915. (i) Sharma, A.; Besnard, C.; Guénée, L.; Lacour, J. Org. Biomol. Chem. 2012, 10, 966. (j) Vanecko, J.A.; Wan, H.; West, F.G. Tetrahedron, 2006, 62, 1043. (k) Kowalkowska, A.; Jończyk, A. Tetrahedron, 2015, 71, 9630. (l) Lahm, G.; Pacheco, J.C.O.; Opatz, T. Synthesis, 2014, 46, 2413.

(4) (a) Hata, Y.; Watanable, M. Tetrahedron Letters, 1972, 13, 3827. (b) Hata, Y.; Watanabe, M. Tetrahedron Letters, 1972, 13, 4659. (c) Bott, T.M.; Vanecko, J.A.; West, F.G. J. Org. Chem. 2009, 74, 2832. (d) Glaeske, K.W.; West, F.G. Org. Lett. 1999, 1, 31. (e) Drouillat, B.; 
d'Aboville, E.; Bourdreux, F.; Couty, F. Eur. J. Org. Chem. 2014, 2014, 1103. (f) Couty, F.; Durrat, F.; Evano, G.; Prim, D. Tetrahedron Letters, 2004, 45, 7525.

(5) Approximately 59\% of all small-molecule drugs contain at least one nitrogen-containing heterocycle: Vitaku, E.; Smith, D.T.; Njardarson, J.T. J. Med. Chem. 2014, 57, 10257.

(6) (a) St. Jean, D. J.; Fotsch, C. J. Med. Chem. 2012, 55, 6002. (b) Wang, D.X.; Booth, H.; Lerner-Marmarosh, N.; Osdene, T.S.; Abood, L.G. Drug Dev. Res. 1998, 45, 10.

(7) (a) Brandi, A.; Cicchi, S.; Cordero, F.M. Chem. Rev. 2008, 108, 3988. (b) Mehra, V.; Lumb, I.; Anand, A.; Kumar, V. RSC Adv. 2017, 7,45763

(8) Lowe, J.T.; Lee, M.D.; Akella, L.B.; Davoine, E.; Donckele, E.J.; Durak, L.; Duvall, J.R.; Gerard, B.; Holson, E.B.; Joliton, A.; Kesavan, S.; Lemercier, B.C.; Liu, H.; Marié, J.-C.; Mulrooney, C.A.; Muncipinto, G.; Welzel-O'Shea, M.; Panko, L.M.; Rowley, A.; Suh, B.-C.; Thomas, M.; Wanger, F.F.; Wei, J.; Foley, M.A.; Marcaurelle, L.A. J. Org. Chem. 2012, 77, 7187 .

(9) (a) Becker, M.R.; Richardson, A.D.; Schindler, C.S. Nat. Commun. 2019, 10, 5095. (b) Becker, R.; Wearing, E.R.; Schindler, C.S. Nat. Chem. 2020, 12, 898. (c) Richardson, A.D.; Becker, M.R.; Schindler, C.S. Chem. Sci. 2020, 11, 7553. (d) Sakamoto, R.; Inada, T.; Sakura, S.; Maruoka, K. Org. Lett. 2016, 18, 6252. (e) Flores, D.; Neville, M.; Schmidt, V. ChemRxiv 2021, doi:10:33774/chemrxiv-2021-t45sg. (10) For selected examples, see: (a) Malik, S.; Nadir, U.K. Synlett, 2008, 108. (b) Han, J.-Q.; Zhang. H.-H.; Xu, P.-F.; Luo, Y.-C. Org. Lett. 2016, 18, 5212. (c) He, G.; Zhao, Y.; Zhang, S.; Lu, C.; Chen, G. J. Am. Chem. Soc. 2012, 134, 3. (d) Zhang. H-H.; Luo, Y.-C.; Wang, H.-P.; Chen. W.; Xu, P.-F. Org. Lett. 2016, 16, 4896. (d) Ma, X.; Zhao, H.; Binayeva, M.; Ralph, G.; Diane, M.; Zhao, S.; Wang, C.-Y.; Biscoe, M.R. Chem, 2020, 6, 781.

(11) Dequina, H.J.; Schomaker, J.M. Trends in Chemistry, 2020, 2, 874.

(12) (a) Rowlands, G.J.; Barnes,W.K. Tetrahedron Letters, 2004, 45, 5347. (b) Dequina, H.J.; Eshon, J.; Raskopf, W.T.; Fernández, I.; Schomaker, J.M. Org. Lett. 2020, 22, 3637. (c) Schmid, S.C.; Guzei, I.A.; Fernández, I.; Schomaker, J.M. ACS Catal. 2018, 8, 7907. (d) Schmid, S.C.; Guzei, I.A.; Schomaker, J.M. Angew. Chem. Int. Ed. 2017, 56, 12229. (e) Clark, J.S.; Hodgson, P.B.; Goldsmith, M.D.; Blake, A.J.; Cooke, P.A.; Street, L.J. J. Chem. Soc. Perkin Trans. 1, 2001, 3325. (f) Eshon, J.; Nicastri, K.A.; Schmid, S.C.; Raskopf, W.T.; Guzei, I.A.; Fernández, I.; Schomaker, J.M. Nat. Commun. 2020, 11, 1273.

(13) (a) Bach, R.; Harthong, S.; Lacour, J. Comprehensive Organic Synthesis II, 2014, 3, 992. (b) Lepley, A.R.; Becker, R.H.; Giumanini, A.G. J. Org. Chem. 1971, 36, 1222.

(14) (a) Qu, J.-P.; Xu, Z.-H.; Zhou, J.; Cao, C.-L.; Sun, X.-L.; Dai, L.-X.; Tang, Y. Adv. Synth. Catal. 2009, 351, 308. (b) Tomooka, K.; Sakamaki, J.; Harada, M.; Wada, R. Synlett, 2008, 5, 683.

(15) (a) Tayama, E.; Nanbara, S.; Nakai, T. Chem. Lett. 2006, 35, 478. (b) Gonçalves-Farbos, M-H.; Vial, L.; Lacour, J. Chem. Commun. 2008, 829. (c) Palombi, L. Catalysis Communications, 2011, 12, 485. (d) Glaeske, K.W.; West, F.G. Org. Lett. 1999, 1, 31. (e) Vial, L.; Gonçalves, M.-H.; Morgantini, P.-Y.; Weber, J.; Bernardinelli, G.; Lacour, J. Synlett, 2004, 9, 1565.

(16) (a) Woodward, J.R. Prog. React. Kinet. Mec. 2002, 27, 165. (b) Franck, J.; Rainbowitsch, E. Trans. Faraday Soc. 1934, 30, 120. (c)
Braden, D.A.; Parrack, E.E.; Tyler, D.R. Coord. Chem. Rev. 2001, 211 279.

(17) For reviews and representative examples, see: (a) Whitehouse, C.J.C.; Bell, S.G.; Wong, L.-L. Chem. Soc. Rev. 2011, 41, 1218. (b) Thiel, D.; Doknić, D.; Deska, J. Nat. Commun. 2014, 5, 5278. (c) Tang, M.-C.; Zou, Y.; Watanabe, K.; Walsh, C.T.; Tang, Y. Chem. Rev. 2017, 117, 5226. (d) Bat-Erdene, U.; Kanayama, D.; Tan, D.; Turner, W.C.; Houk, K.N.; Ohashi, M.; Tang, Y. J. Am. Chem. Soc. 2000, 142, 8550. (e) Fürst, M.J.L.; Gran-Scheuch, A.; Aalbers, F.S.; Fraaije, M.W. ACS Catal. 2019, 9, 11207. (f) Leisch, H.; Morley, K.; Lau, P.C.K. Chem. Rev. 2011, 111, 4165. (g) Deska, J.; Thiel, D.; Gianolio, E. Synthesis, 2015, 47, 3435.

(18) For reviews and representative examples, see: (a) Christianson, D.W. Chem. Rev. 2017, 117, 11570. (b) Hoshino, T.; Kouda, M.; Abe, T.; Ohashi, S. Biosci. Biotechnol. Biochem. 1999, 63, 2038. (c) Xu, M.; Jia, M.; Hong, Y.J.; Yin. X.; Tantillo, D.J.; Proteau, P.J.; Peters, R.J. Org. Lett. 2018, 20, 1200. (d) Quan, Z.; Dickschat, J.S. Org. Lett. 2020, 22, 7552. (e) Xu, R.; Fazio, G.C.; Matsuda, S.P.T. Phytochemistry, 2004, 65, 261. (f) Rudolf, J.D.; Chang, C.-Y. Nat. Prod. Rep. 2020, 37, 425. (g) Dickschat, J.S. Angew. Chem. Int. Ed. 2019, 58, 15964.

(20) (a) Brandenberg, O.F.; Fasan, R.; Arnold, F.H. Curr. Opin. Biotechnol. 2017, 47, 102. (b) Yang, Y.; Arnold, F.H. Acc. Chem. Res. 2021, 54, 1209. (c) Liu, Z.; Arnold, F.H. Curr. Opin. Biotechnol. 2021, 69, 43. (d) Dunham, N.P.; Arnold, F.H. ACS Catal. 2020, 10, 12239.

(21) (a) Chen, K.C.; Arnold, F.H. J. Am. Chem. Soc. 2020, 142, 6891. (b) Chen, K.C.; Huang, X.; Kan, S.B.J.; Zhang, R.K.; Arnold, F.H. Science, 2018, 360, 71.

(22) (a) Kan, S.B.J.; Lewis, R.D.; Chen, K.; Arnold, F.H. Science, 2016, 354, 1048. (b) Kan, S.B.J.; Huang, X.; Gumulya, Y.; Chen, K.; Arnold, F.H. Nature, 2017, 552, 132. (c) Zhang, R.K.; Chen. K.; Huang, X.; Wohlschlager, L.; Renata, H.; Arnold, F.H. Nature, 2019, 565, 67. (d) Chen, K.; Zhang, S.-Q.; Brandenberg, O.F.; Hong, X.; Arnold, F.H. J. Am. Chem. Soc. 2018, 140, 16402.

(20) (a) Wang, Z.J.; Peck. N.E.; Renata, H.; Arnold, F.H. Chem. Sci. 2014, 5, 598. (b) Steck, V.; Carminati, D.M.; Johnson, N.R.; Fasan, R. ACS Catal. 2020, 10, 10967. (c) Sreenilayam, G.; Fasan, R. Chem. Commun. 2015, 15, 1532. (d) Sreenilayam, G.; Moore, E.J. Steck, V.; Fasan, R. Adv. Synth. Catal. 2017, 359, 2076. (d) Steck, V.; Sreenilayam, G.; Fasan, R. Synlett, 2020, 31, 224. (e) Liu, Z.; Calvó-Tusell, C.; Zhou, A.Z.; Chen, K.; Garcia-Borrás, M.; Arnold, F.H. ChemRxiv, 2021, doi: 10.26434/chemrxiv.14452158.v1.

(23) Ortiz de Montellano, P.R. Chem. Rev. 2010, 110, 932.

(24) Yang, Y.; Cho, I.; Qi, X.; Liu, P.; Arnold, F.H. Nat. Chem. 2019, 11, 987.

(25) Coelho, P.S.; Wang, Z.J.; Ener, M.E.; Baril, S.A.; Kannan, A.; Arnold, F.H.; Brustad, E.M. Nat. Chem. Biol. 2013, 9, 485.

(26) Brandenberg, O.F.; Prier, C.K.; Chen, K.; Knight, A.M.; Wu, Z.; Arnold, F.H. ACS Catal. 2018, 8, 2629.

(27) Narhi, L.O.; Fulco, A.J. J. Biol. Chem. 1986, 261, 7160.

(28) Waser, M.; Moher, E.D.; Borders, S.S.K.; Hansen, M.M.; Hoard, D.W.; Laurila, M.E.; LeTourneau, M.E.; Miller, R.D.; Phillips, M.L.; Sullivan, K.A.; Ward, J.A.; Xie, C.; Bye, C.A.; Leitner, T.J.; HerzogKrimbacher, B.; Kordian, M.; Müllner, M. Org. Process Res. Dev. 2011, 15, 1266

(29) Zhang, J.; Huang, X.; Zhang, R.K.; Arnold, F.H. J. Am. Chem. Soc. 2019, 141, 9798. 

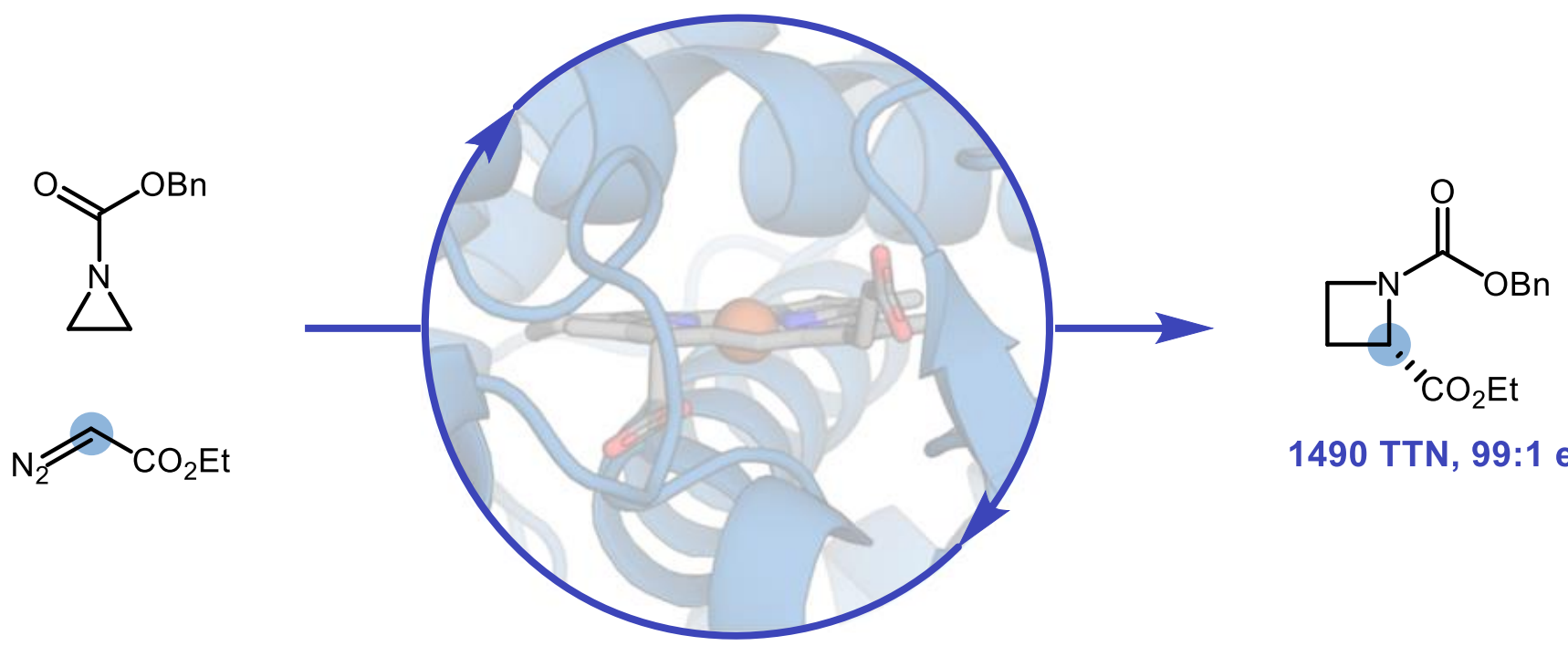

1490 TTN, 99:1 er

Highly chemo- and stereoselective rearrangement of aziridinium ylides 